\title{
Pengaruh Kredit Yang Disalurkan Pada Profitabilitas Dengan Ukuran Perusahaan Sebagai Variabel Pemoderasi
}

\author{
Made Widi Artha ${ }^{1}$ \\ I Gst. Ayu Eka Damayanthi ${ }^{2}$ \\ ${ }^{1,2}$ Fakultas Ekonomi dan Bisnis Universitas Udayana (Unud), Bali, Indonesia \\ e-mail: widiartha997@gmail.com
}

\begin{abstract}
ABSTRAK
Penelitian ini bertujuan untuk mendapatkan bukti empiris mengenai pengaruh kredit yang disalurkan pada profitabilitas, serta pengaruh ukuran perusahaan terhadap hubungan kredit yang disalurkan pada profitabilitas. Penelitian ini dilakukan di perusahaan subsektor perbankan yang terdaftar di Bursa Efek Indonesia periode 2013 hingga 2017. Sampel ditentukan menggunakan metode purposive sampling, dan jumlah yang diperoleh yaitu 120 observasian. Teknik Analisis data yang digunakan yaitu uji Regresi Linear Sederhana dan Moderated Regression Analysis (MRA). Berdasarkan hasil analisis ditemukan bahwa kredit yang disalurkan berpengaruh positif signifikan pada profitabilitas dan ukuran perusahaan memperlemah hubungan kredit yang disalurkan pada profitabilitas. Implikasi teoritis dari penelitian ini adalah untuk menambah wawasan dan pengetahuan pembaca serta sebagai tambahan referensi pada penelitian selanjutnya. Implikasi praktis penelitian adalah sebagai tambahan informasi bagi pihak perusahaan bank dalam mengambil keputusan dan investor sebelum melakukan investasi.
\end{abstract}

Kata kunci: Profitabilitas, Kredit yang Disalurkan, dan Ukuran Perusahaan.

\begin{abstract}
This study aims to obtain empirical evidence the effect of distributed credit on profitability, and the influence of company size on distributed credit to profitability relation. This research was conducted in the banking sub-sector companies listed on the Indonesia Stock Exchange from 2013 to 2017. The samples were determined using purposive sampling method, and the amount obtained was 120 observations. The data analysis technique used is Simple Linear Regression test and Moderated Regression Analysis (MRA). Based on the results of the analysis it was found that the distributed credit had a positive effect on profitability and the size of the company weakened the relation of distributed credit to profitability. The theoretical implications are to add insight and knowledge of the reader and additional reference to further research. The practical implications are as additional information for the bank companies in making decisions and investors before making an investment.

Keywords: Profitability, Distributed Credit, and Company Size.
\end{abstract}

\section{PENDAHULUAN}

Kehadiran bank sebagai salah satu lembaga keuangan memberikan kontribusi yang sangat penting dalam keuangan suatu negara. Prinsip yang mendasari kegiatan usaha bank adalah kepercayaan masyarakat. Kepercayaan masyarakat 
dalam menyimpan dana di bank dipengaruhi oleh informasi yang diperolehnya mengenai kualitas dan kinerja bank yang bersangkutan dengan salah satu indikatornya adalah tingkat kesehatan bank (Oktaviani dan Yusuf, 2014). Tingkat kesehatan bank adalah penilaian atas suatu kondisi laporan keuangan bank pada suatu periode tertentu sesuai dengan standar Bank Indonesia. Penilaian untuk menentukan kondisi suatu bank biasanya menggunakan analisis CAMELS, dengan salah satu aspeknya berupa earnings atau tingkat profitabilitas bank. Faktor penentu profitabilitas dibagi dalam dua kategori utama, yaitu internal (likuiditas, kecukupan modal dan manajemen biaya) dan eksternal (kepemilikan, ukuran perusahaan dan kondisi ekonomi eksternal) (Naceur dan Omran, 2008).

Profitabilitas memiliki arti penting dalam usaha untuk mempertahankan kelangsungan hidupnya dalam jangka panjang, karena profitabilitas menunjukkan apakah badan usaha tersebut mempunyai prospek yang baik di masa yang akan datang (Haneef et al., 2012). Tingkat kinerja profitabilitas suatu perusahaan dapat dilihat dan diukur melalui laporan keuangan dengan cara menganalisis dan menghitung rasio-rasio dalam kinerja keuangan. Surat Edaran Bank Indonesia No. 06/23/DPNP tanggal 31 Mei 2004 mengemukakan terdapat tiga rasio yang digunakan sebagai parameter dari profitabilitas bank, yakni Return On Assets (ROA), Return On Equity (ROE) dan Net Interest Margin (NIM). Penelitian ini menggunakan ROA sebagai parameter untuk menilai profitabilitas karena menunjukkan perbandingan antara laba (sebelum pajak) dengan rata-rata total aset bank, selain itu rasio ini juga menunjukkan tingkat efisiensi manajemen aset yang dilakukan oleh pihak bank terkait untuk mengukur kemampuan manajemen bank 
dalam menghasilkan laba secara keseluruhan (Hantono, 2017). ROA yang meningkat juga menunjukkan bahwa perusahaan memiliki prospek yang baik kedepannya karena perusahaan memiliki potensi untuk meningkatkan perolehan keuntungan.

Bank selain memiliki peranan dalam stabilitas ekonomi suatu negara juga memiliki fungsi sebagai lembaga perantara keuangan (financial intermediary) untuk menghimpun dana (funding) dan menyalurkan dana (lending) antara pihakpihak yang memiliki dana (surplus) dengan pihak-pihak yang memerlukan dana (deficit) sehingga dapat meningkatkan taraf hidup masyarakat. Dalam menjalankan fungsinya, bank membantu koperasi, pengusaha kecil dan menengah maupun masyarakat umum dalam mendirikan sebuah usaha ataupun investasi melalui aktivitas penyaluran kredit. Kredit dan deposito merupakan salah satu faktor utama untuk menentukan profitabilitas bank (Rengasamy, 2014).

Berdasarkan teori abstinence seseorang yang menyimpan uangnya dan meminjamkannya, memiliki hak untuk mendapatkan imbalan berupa bunga (Bećirović, 2015) dan jika dilihat dalam dunia perbankan, kredit yang disalurkan oleh bank kepada masyarakat tentunya akan menghasilkan pendapatan bunga. Pendapatan bunga tersebut merupakan salah satu sumber pendapatan bank untuk menghasilkan laba, jika bank tersebut dapat memanfaatkan dengan optimal dana pihak ketiga yang telah dihimpun. Kredit yang disalurkan oleh bank dapat dilihat melalui rasio Loan to Deposit Ratio (LDR). Loan to Deposit Ratio merupakan perbandingan total kredit yang disalurkan terhadap dana pihak ketiga yang dihimpun oleh bank. LDR memiliki peranan penting sebagai indikator yang 
menunjukkan tingkat ekspansi kredit yang disalurkan oleh bank, sehingga LDR dapat juga digunakan untuk mengukur berjalan atau tidaknya suatu fungsi intermediasi bank tersebut (Utami dan Putra, 2016). LDR selain digunakan untuk mengukur tingkat kredit yang disalurkan, juga berkaitan dengan likuiditas sebuah industri perbankan sehingga bank harus dapat menjaga rasio LDR pada batas yang sudah ditentukan dengan tujuan agar bank tidak berlebihan memberi kredit yang berasal dari simpanan masyarakat. Hal tersebut didukung oleh penelitian yang dilakukan Utami (2015) yang menunjukkan hasil bahwa LDR berpengaruh positif dan signifikan terhadap ROA. Berikut ini merupakan Tabel 1 yang menampilkan perkembangan ROA dan LDR pada Bank Umum Konvensional tahun 2013-2017:

Tabel 1.

Rasio Kinerja Bank Umum Konvensional Tahun 2013-2017

\begin{tabular}{cccccc}
\hline \multirow{2}{*}{ Variabel } & \multicolumn{5}{c}{ Tahun } \\
& 2013 & 2014 & 2015 & 2016 & 2017 \\
\hline ROA (\%) & 3,08 & 2,85 & 2,32 & 2,23 & 2,45 \\
LDR (\%) & 89,70 & 89,42 & 92,11 & 90,70 & 90,04 \\
\hline
\end{tabular}

Sumber: Statistik Perbankan Indonesia, 2018

Berdasarkan tabel tersebut, secara umum subsektor perbankan mengalami penurunan kinerja yang dapat dilihat melalui rasio ROA dikarenakan rasio tersebut secara terus menerus mengalami penurunan dari tahun 2013 hingga tahun 2016 yang mencapai 0,85 persen, namun mengalami peningkatan di tahun 2017 . Dapat dilihat juga bahwa rasio LDR mengalami kondisi yang fluktuatif. Tahun 2013 hingga tahun 2014 rasio LDR mengalami penurunan sebesar 0,28 persen. Tahun berikutnya rasio LDR mengalami peningkatan sebesar 2,69 persen kemudian secara berlanjut mengalami penurunan hingga tahun 2017. Kondisi 
tersebut menunjukan adanya hubungan tidak searah antara rasio LDR dengan ROA.

Penelitian terkait profitabilitas pada perusahaan perbankan sudah banyak dilakukan dan dibuktikan secara empiris, namun menunjukkan hasil yang tidak konsisten. Penelitian yang dilakukan oleh Hantono, (2017), Harun (2016), Munir dan Emdi (2017) serta Risha (2013) menunjukkan bahwa peningkatan Loan to Deposit Ratio (LDR) berpengaruh positif dan berdampak signifikan terhadap ROA. Hasil penelitian Bwacha dan Xi (2018), Christaria dan Kurnia (2016), Permatasari dkk., (2017) serta Zainuddin et al., (2017) menunjukkan perbedaan, yaitu peningkatan LDR tidak berdampak signifikan atau berpengaruh negatif terhadap ROA. Penelitian lainnya dilakukan juga oleh Rengasamy (2014) dan menunjukkan hasil yang beragam yakni diantara 8 (delapan) sampel bank yang diteliti, terdapat 6 (enam) bank yang memiliki pengaruh positif namun tidak signifikan antara LDR pada ROA, 1 (satu) bank berpengaruh positf dan signifikan antara LDR terhadap ROA dan 1 (satu) bank memiliki pengaruh negatif dan tidak signifikan antara LDR terhadap ROA. Hal tersebut mendorong peneliti untuk melakukan penelitian lebih lanjut mengenai pengaruh jumlah kredit yang disalurkan pada profitabilitas karena kemungkinan terdapat faktor lain yang turut mempengaruhi hubungan tersebut, sehingga dalam penelitian ini menambahkan ukuran perusahaan sebagai variabel moderasi.

Ukuran perusahaan (firm size) merupakan suatu ukuran yang menunjukkan besar kecilnya suatu perusahaan. Besar kecilnya perusahaan akan mempengaruhi kemampuan dalam menanggung risiko seperti risiko kredit maupun risiko 
operasional yang timbul dari berbagai kegiatan serta situasi yang dihadapi oleh perusahaan perbankan. Dalam teori keageanan, ukuran perusahaan juga dapat memicu adanya agency problem yang menimbulkan agency cost. Kondisi tersebut terjadi apabila semakin besar ukuran perusahaan didukung oleh tidak adanya keselarasan insentif antara principal (deposan) dan agent (manajemen) sehingga manajemen bank mengambil keputusan secara sepihak untuk melakukan investasi berisiko tinggi dalam penggunaan dana masyarakat karena menginginkan keuntungan pribadi yang berdampak pada profitabilitas perusahaan, maka dari itu ukuran perusahaan sebagai variabel moderasi diduga dapat mempengaruhi hubungan kredit yang disalurkan pada profitabilitas. Skala klasifikasi besar kecilnya perusahaan dapat menggunakan berbagai cara antara lain dengan total aktiva, log size, nilai pasar saham, dan lain-lain (Adawiyah dan Suprihhadi, 2017). Penelitian ini menggunakan nilai pasar saham yang kemudian disebut kapitalisasi pasar sebagai skala untuk melihat ukuran perusahaan. Teori Basel II mengungkapkan kegiatan penyalurkan kredit dapat menimbulkan adanya risiko kredit, sehingga pihak bank harus memenuhi tingkat kecukupan modal untuk dapat menghadapi risiko tersebut. Salah satu cara untuk memenuhi tingkat kecukupan modal yaitu melalui peningkatan kapitalisasi pasar yang juga merupakan cerminan dari ukuran perusahaan. Kapitalisasi pasar menggambarkan potensi pertumbuhan perusahaan yang bagus serta memiliki risiko yang rendah (Japlani, 2015). Peningkatan penjualan saham dapat digolongkan bahwa bank memiliki peningkatan laba dan adanya permintaan saham dari masyarakat menyebabkan pihak bank akan mendapatkan modal dari pembelian saham 
tersebut sehingga perusahaan akan dapat memperbesar volume penyaluran kredit (Pramudita, 2013). Sufian (2011) mengungkapkan bahwa kapitalisasi pasar saham berpengaruh positif signifikan pada profitabilitas bank. Goddard et al., (2004) juga menyatakan bahwa ukuran bank dapat secara langsung menentukan profitabilitas bank, dan Arif et al., (2013) mengungkapkan bahwa ukuran perusahaan berpengaruh positif terhadap ROA.

Penelitian ini berlokasi di Bursa Efek Indonesia pada perusahaan subsektor perbankan, dikarenakan mengacu pada Peraturan Bank Indonesia Nomor 6/10/PBI/2004 tentang sistem penilaian tingkat kesehatan bank umum bahwa kesehatan suatu bank merupakan kepentingan semua pihak yang terkait, baik pemilik, pengelola bank, masyarakat pengguna jasa bank dan Bank Indonesia selaku otoritas pengawasan bank serta Peraturan Bank Indonesia Nomor: 13/1/PBI/2011 bahwa bank wajib melakukan penilaian tingkat kesehatan bank secara individual. Saham pada subsektor perbankan juga menjadi salah satu saham yang diminati oleh investor karena memiliki potensi pertumbuhan dan menghasilkan laba yang cukup bagus dari waktu ke waktu disebabkan oleh banyaknya individu maupun perusahaan yang selalu membutuhkan jasa perbankan. Pemilihan periode penelitian tahun 2013-2017 bertujuan untuk memperoleh data terbaru mengenai kondisi keuangan pada subsektor perbankan, selain itu juga objek penelitian terdahulu terbatas pada perusahaan perbankan yang terdaftar di Bursa Efek Indonesia hanya dengan 3 (tiga) tahun periode penelitian, sehingga peneliti memperpanjang periode penelitian menjadi 5 (lima) tahun. 
Berdasarkan penjelasan di atas, maka tujuan penelitan ini adalah untuk mengetahui pengaruh kredit yang disalurkan pada profitabilitas dan untuk mengetahui moderasi ukuran perusahaan terhadap hubungan antara kredit yang disalurkan pada profitabilitas. Berdasarkan landasan teori dan kajian empiris yang telah disampaikan, maka skema kerangka konseptual dalam penelitian ini dapat digambarkan pada Gambar 1 sebagai berikut:

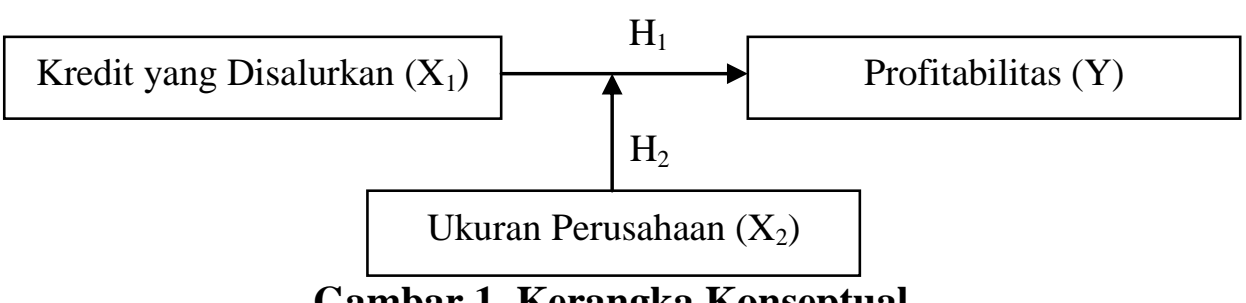

Sumber: Data diolah, 2018

\section{Gambar 1. Kerangka Konseptual}

Berdasarkan pada tujuan penelitian dan kajian-kajian teori yang relevan ataupun hasil dari penelitian yang sebelumnya, maka hipotesis dalam penelitian ini adalah sebagai berikut:

$\mathrm{H}_{1}$ : Kredit yang disalurkan berpengaruh positif terhadap profitabilitas.

$\mathrm{H}_{2}$ : Ukuran perusahaan memperkuat hubungan antara kredit yang disalurkan dengan profitabilitas

\section{METODE PENELITIAN}

Penelitian ini merupakan jenis penelitian kuantitatif, yaitu penelitian yang berlandaskan pada filsafat positivisme digunakan untuk meneliti pada populasi atau sampel tertentu, analisis data bersifat kuantitatif/statistik, dengan tujuan untuk menguji hipotesis yang telah ditetapkan (Sugiyono, 2017: 8) serta pendekatan asosiatif, yaitu penelitian yang meneliti pengaruh suatu variabel 
terhadap variabel lainnya atau untuk mengetahui hubungan antara dua variabel atau lebih (Sugiyono, 2017: 37).

Penelitian ini dilakukan pada perusahaan subsektor perbankan yang terdaftar di Bursa Efek Indonesia pada periode 2013-2017 dengan mengakses situs Bursa Efek Indonesia yakni www.idx.co.id. Obyek yang menjadi kajian dalam penelitian ini adalah pengaruh kredit yang disalurkan terhadap profitabilitas dengan ukuran perusahaan sebagai variabel pemoderasi pada perusahaan subsektor perbankan yang terdaftar di Bursa Efek Indonesia periode 2013-2017.

Penelitian ini menggunakan tiga jenis variabel, yaitu: Variabel terikat (dependen), variabel bebas (independen) dan variabel pemoderasi. Variabel dependen yang digunakan adalah profitabilitas (Y) dengan proksi yakni Return On Assets (ROA) yang dapat dihitung dengan menggunakan rumus:

ROA $=\frac{\text { Laba Sabelum Pajak }}{\text { Rata-Rata Total Altiva }} \times 100 \%$

Variabel independen pada penelitian ini yaitu kredit yang disalurkan $\left(\mathrm{X}_{1}\right)$ yang diproksikan dengan Loan to Deposit Ratio (LDR). LDR selain mengukur kredit yang disalurkan, juga berkaitan dengan likuiditas sebuah industri perbankan sehingga bank harus dapat menjaga rasio LDR pada batas yang sudah ditentukan dengan tujuan agar bank tidak berlebihan memberi kredit yang berasal dari simpanan masyarakat. Menurut Hidayat dkk., (2012) rasio LDR mengukur pinjaman yang diberikan dibandingkan dengan dana pihak ketiga (giro, tabungan dan deposito). Rumus Loan to Deposit Ratio berdasarkan Surat Edaran Bank Indonesia No. 06/23/DPNP tanggal 31 Mei 2004 yakni: 
$\mathrm{LDR}=\frac{\text { Jumlah Kradit yang Disalurkan }}{\text { Dana Pihalk Ketiga }} \times 100 \%$

Variabel pemoderasi dalam penelitian ini adalah Ukuran Perusahaan $\left(\mathrm{X}_{2}\right)$. Skala klasifikasi ukuran perusahaan dapat menggunakan bentuk logaritma natural dari tiga ukuran ukuran perusahaan, yaitu total aset, total penjualan, dan nilai pasar saham (Dang et al., 2018), dan penelitian ini menggunakan nilai pasar saham atau yang kemudian disebut kapitalisasi pasar. Ukuran perusahaan diproksikan dengan logaritma natural kapitalisasi pasar untuk mengurangi fluktuasi data berlebih, dan tingkat kapitalisasi pasar dihitung dengan rumus sebagai berikut (Pramudita, 2013):

$$
\left(\mathrm{V}_{\mathrm{s}}=\mathrm{P}_{\mathrm{s}} \times \mathrm{S}_{\mathrm{s}}\right)
$$

Keterangan:

$\mathrm{V}_{\mathrm{s}}=$ Market value

$\mathrm{P}_{\mathrm{s}}=$ Market price (harga pasar saham)

$\mathrm{S}_{\mathrm{s}}=$ Outstanding shares (jumlah saham yang diterbitkan)

Populasi dalam penelitian ini adalah seluruh perusahaan subsektor perbankan yang terdaftar di Bursa Efek Indonesia (BEI) tahun 2013-2017, sebanyak 43 perusahaan. Sampel pada penelitian ini adalah perusahaan subsektor perbankan yang terdaftar di BEI tahun 2013-2017 dan sesuai dengan kriteria pada teknik penentuan sampel. Pemilihan sampel dilakukan secara purposive bertujuan untuk memperoleh sampel yang representatif berdasarkan kriteria bahwa sampel merupakan perusahaan subsektor perbankan yang tidak melakukan listing di Bursa Efek Indonesia setelah tahun 2013, sampel perusahaan rutin mempublikasikan laporan tahunan (annual report) dalam periode penelitian 20132017 serta memiliki data yang lengkap dalam laporan tahunan terkait dengan 
variabel-variabel yang digunakan dalam penelitian dan memperoleh laba dalam periode pengamatan 2013-2017.

Penelitian ini menggunakan analisis regresi linear sederhana dan moderated regression analysis sebagai teknik analisis data. Namun, sebelum melakukan pengujian analisis regresi, dilakukan uji statistik deskriptif dan uji asumsi klasik terlebih dahulu agar variabel yang digunakan bebas dari adanya penyimpangan. Analisis regresi linear sederhana dalam penelitian ini bertujuan untuk mengetahui pengaruh kredit yang disalurkan terhadap profitabilitas. Adapun persamaan regresi yang dihasilkan dari model regresi sederhana dalam penelitian ini adalah:

$\mathrm{Y}=\alpha+\beta_{1} \mathrm{X}_{1}+\varepsilon$

Keterangan:

$\mathrm{Y}=$ Profitabilitas

$\alpha \quad=$ Konstanta

$\beta_{1}=$ Koefisien regresi variabel kredit yang disalurkan

$\mathrm{X}_{1} \quad=$ Kredit yang disalurkan

$\varepsilon \quad=$ Error

Selanjutnya untuk mengetahui pengaruh ukuran perusahaan dalam memoderasi hubungan kredit yang disalurkan dengan profitabilitas digunakan uji Moderated Regression Analysis. MRA dipilih dalam penelitian ini karena dapat menjelaskan pengaruh variabel pemoderasi dalam memperkuat maupun memperlemah hubungan variabel independen dengan variabel dependen, dengan rumus persamaan berikut:

$Y=\alpha+\beta_{1} X_{1}+\beta_{2} X_{2}+\beta_{3} X_{1} X_{2}+\varepsilon$

Keterangan:

$\mathrm{Y}=$ Profitabilitas

$\alpha \quad=$ Konstanta

$\beta_{1} \quad=$ Koefisien regresi variabel kredit yang disalurkan

$\beta_{2} \quad=$ Koefisien regresi variabel ukuran perusahaan 
$\beta_{3}=$ Koefisien regresi interaksi antara variabel kredit yang disalurkan dengan variabel ukuran perusahaan

$\mathrm{X}_{1} \quad=$ Kredit yang disalurkan

$\mathrm{X}_{2}=$ Ukuran perusahaan

$\mathrm{X}_{1} \mathrm{X}_{2}=$ Interaksi antara variabel kredit yang disalurkan dengan variabel ukuran perusahaan

$\varepsilon \quad=$ Error

Koefisien $\beta_{3}$ merupakan koefisien perkalian antara $X_{1}$ dan $X_{2}$ atau $X_{1} X_{2}$ yang merupakan merupakan variabel moderasi karena menggambarkan pengaruh moderasi variabel ukuran perusahaan terhadap hubungan kredit yang disalurkan pada profitabilitas.

\section{HASIL DAN PEMBAHASAN}

Populasi pada penelitian ini merupakan perusahaan subsektor perbankan yang terdaftar di Bursa Efek Indonesia periode 2013 hingga 2017 yang secara rinci dapat dilihat dalam Tabel 2.

Tabel 2.

Jumlah Perusahaan Subsektor Perbankan Tahun 2013-2017

\begin{tabular}{|c|c|c|c|}
\hline Tahun & Keterangan & Jumlah Perusahaan & Total Perusahaan \\
\hline \multirow[t]{2}{*}{2013} & Perusahaan listing & 4 & \\
\hline & Perusahaan terdaftar & & 36 \\
\hline \multirow[t]{2}{*}{2014} & Perusahaan listing & 4 & \\
\hline & Perusahaan terdaftar & & 40 \\
\hline \multirow[t]{3}{*}{2015} & Perusahaan listing & 2 & \\
\hline & Perusahaan delisting & (1) & \\
\hline & Perusahaan terdaftar & & 41 \\
\hline \multirow[t]{2}{*}{2016} & Perusahaan listing & 2 & \\
\hline & Perusahaan terdaftar & & 43 \\
\hline \multirow[t]{2}{*}{2017} & Perusahaan listing & 0 & \\
\hline & Perusahaan terdaftar & & 43 \\
\hline
\end{tabular}

Sumber: Data diolah, 2018

Tahun 2013 terdapat empat perusahaan perbankan yang melakukan listing, yaitu Bank Mestika Dharma, Bank Maspion Indonesia, Bank Mitraniaga, dan 
Bank Nationalnobu. Empat perusahaan berikutnya melakukan listing pada tahun 2014, yaitu Bank Agris, Bank Ina Perdana, Bank Dinar Indonesia, dan Bank Panin Syariah. Tahun 2015 terdapat dua perusahaan yang listing yaitu Bank Harda Internasional dan Bank Yudha Bhakti, namun Bank Ekonomi Raharja delisting. Tahun 2016 terdapat dua perusahaan perbankan yang listing, yaitu Bank Artos Indonesia dan Bank Ganesha. Dapat disimpulkan bahwa terdapat 44 perusahaan subsektor perbankan yang terdafatar di BEI dalam tahun 2013-2017, namun 8 perusahaan melakukan listing setelah tahun 2013 dan 1 perusahaan melakukan delisting setelah tahun 2013. Jumlah perusahaan yang listing serta delisting tersebut nantinya akan mempengaruhi jumlah sampel yang digunakan, sesuai dengan kriteria purposive sampling yang telah dijabarkan.

Metode penentuan sampel dalam penelitian ini menggunakan metode non probability dengan teknik purposive sampling, dan berdasarkan hasil observasi, maka perusahaan subsektor perbankan yang dapat dijadikan sampel berjumlah sebanyak 27 perusahaan, diobservasi selama 5 tahun sehingga diperoleh 135 observasian dan dalam data tersebut terdapat data outlier sebanyak 15 sehingga total observasi yang digunakan sebanyak 120 sampel. Proses seleksi sampel disajikan pada Tabel 3 . 
Tabel 3.

Proses Seleksi Sampel

\begin{tabular}{llc}
\hline No & \multicolumn{1}{c}{ Kriteria } & Jumlah \\
\hline 1 & Perusahaan subsektor perbankan yang listing di BEI tahun 2013-2017. & 43 \\
2 & $\begin{array}{l}\text { Perusahaan subsektor perbankan yang melakukan listing di BEI setelah tahun } \\
\text { 2013. }\end{array}$ & $(8)$ \\
3 & $\begin{array}{l}\text { Perusahaan subsektor perbankan yang tidak rutin mempublikasikan laporan } \\
\text { tahunan (annual report) dalam periode penelitian 2013-2017 dan tidak memiliki }\end{array}$ & \\
& $\begin{array}{l}\text { data lengkap dalam laporan tahunan terkait dengan variabel-variabel yang } \\
\text { digunakan dalam penelitian. }\end{array}$ & \\
4 & $\begin{array}{l}\text { Perusahaan subsektor perbankan yang mengalami kerugian dalam periode } \\
\text { pengamatan 2013-2017. }\end{array}$ & $(6)$ \\
& Jumlah perusahaan yang lulus kriteria sampel & 27 \\
& Jumlah pengamatan penelitian (27 x 5 tahun) & 135 \\
& $\begin{array}{l}\text { Data } \text { outlier } \\
\text { Total sampel penelitian }\end{array}$ & $(15)$ \\
\hline
\end{tabular}

Sumber: Data diolah, 2018

Statistik deskriptif digunakan untuk memberikan gambaran dari suatu data yang dilihat dari nilai minimum, maksimum, mean, serta standar deviasi dari masing-masing varabel penelitian. Hasil dari statistik deskriptif tersebut dapat dilihat pada Tabel 4 berikut:

Tabel 4.

Hasil Statistik Deskriptif

\begin{tabular}{lccccc}
\hline & N & Minimum & Maximum & Mean & Std. Deviation \\
\hline ROA & 120 & 0,09 & 5,14 & 1,66 & 0,90 \\
LDR & 120 & 42,02 & 140,72 & 83,48 & 15,60 \\
Kapitalisasi & 120 & 26,37 & 33,55 & 29,48 & 1,69 \\
Pasar & & & & & \\
Valid $N$ & 120 & & & & \\
(listwise) & & & & &
\end{tabular}

Berdasarkan Tabel 4 diketahui bahwa terdapat tiga variabel dalam penelitian ini, yaitu profitabilitas diproksikan dengan ROA, kredit yang disalurkan diproksikan dengan LDR, dan ukuran perusahaan dengan proksi kapitalisasi pasar. Jumlah pengamatan (N) dalam penelitian ini berjumlah 120. Nilai minimum pada 
variabel ROA sebesar 0,09, sedangkan nilai maksimum sebesar 5,14 dan nilai rata-rata pada variabel ROA sebesar 1,66. Deviasi standar variabel ROA sebesar 0,90 yang menunjukan bahwa standar penyimpangan data terhadap nilai rata-rata sebesar 0,90. Nilai minimum pada variabel LDR sebesar 42,02, sedangkan nilai maksimum sebesar 140,72 dan nilai rata-rata pada variabel LDR sebesar 83,48. Deviasi standar variabel LDR sebesar 15,60 yang menunjukan bahwa standar penyimpangan data terhadap nilai rata-rata sebesar 15,60 . Nilai minimum pada variabel kapitalisasi pasar sebesar 26,37, sedangkan nilai maksimum sebesar 33,55 dan nilai rata-rata pada variabel kapitalisasi pasar sebesar 29,48. Deviasi standar variabel kapitalisasi pasar sebesar 1,69 yang menunjukan bahwa standar penyimpangan data terhadap nilai rata-rata sebesar 1,69.

Seluruh uji asumsi klasik dalam penelitian ini sudah memenuhi kriteria, sehingga data layak di analisis lebih lanjut. Analisis pengujian hipotesis pertama untuk mengetahui pengaruh kredit yang disalurkan pada profitabilitas dalam penelitian ini menggunakan analisis regresi linear sederhana.

Tabel 5.

\section{Hasil Uji Regresi Linear Sederhana}

\begin{tabular}{|c|c|c|c|c|c|c|}
\hline \multirow{2}{*}{\multicolumn{2}{|c|}{ Model }} & \multicolumn{2}{|c|}{$\begin{array}{c}\text { Unstandardized } \\
\text { Coefficients }\end{array}$} & \multirow{2}{*}{$\begin{array}{c}\text { Standardized } \\
\text { Coefficients } \\
\text { Beta }\end{array}$} & \multirow[t]{2}{*}{$t$} & \multirow[t]{2}{*}{ Sig. } \\
\hline & & $B$ & Std. Error & & & \\
\hline \multirow[t]{2}{*}{1} & (Constant) & $-0,513$ & 0,403 & & $-1,272$ & 0,206 \\
\hline & LDR & 0,026 & 0,005 & 0,449 & 5,458 & 0,000 \\
\hline
\end{tabular}

Sumber: Data diolah, 2018

Berdasarkan hasil uji regresi linear sederhana pada Tabel 5, maka dapat dibuat persamaan regresi sebagai berikut:

$$
\mathrm{Y}=-0,513+0,026 \mathrm{X}_{1}+0,403
$$


Interpretasi dari persamaan diatas yaitu jika nilai konstanta sebesar -0,513 memiliki arti jika variabel LDR dinyatakan konstan pada angka 0 , maka variabel ROA bernilai sebesar -0,513. Koefisien regresi pada variabel LDR sebesar 0,026. Koefisien regresi yang bernilai positif memiliki arti jika LDR meningkat sebesar satu satuan, maka ROA juga akan meningkat sebesar 0,026 satuan.

Hasil pengujian statistik pengaruh kredit yang disalurkan terhadap profitabillitas pada Tabel 5 menunjukkan bahwa koefisien regresi dari variabel kredit yang disalurkan dengan proksi LDR adalah 0,026 dan nilai signifikansinya adalah 0,000 yaitu lebih kecil dari $\alpha=0,05$ yang berarti kredit yang disalurkan yang diproksikan dengan LDR berpengaruh positif signifikan terhadap profitabilitas dengan menggunakan proksi ROA, sehingga hipotesis yang diajukan dalam penelitian ini diterima.

Dalam model regresi linear sederhana, koefisien determinasi dilihat melalui nilai $\mathrm{R}^{2}$. Adapun nilai dari nilai $\mathrm{R}^{2}$ dapat dilihat pada Tabel 6 .

Tabel 6.

Koefisien Determinasi $\left(\mathbf{R}^{\mathbf{2}}\right)$

\begin{tabular}{ccccc}
\hline Model & $R$ & $R$ Square & Adjusted $R$ Square & Error of the Estimate \\
\hline 1 & $0,449^{\mathrm{a}}$ & 0,202 & 0,195 & 0,80830 \\
\hline \multicolumn{2}{l}{ Sumber: Data diolah, 2018} & & &
\end{tabular}

Berdasarkan pada Tabel 6 diatas, dapat dilihat bahwa nilai dari $R$ square sebesar 0,202 dimana memiliki arti bahwa 20,2 persen variasi perubahan ROA dapat dijelaskan oleh LDR. Sedangkan sisanya sebesar 79,8 persen dipengaruhi oleh variabel lain diluar dari model regresi yang digunakan Adapun hasil dari uji F telah disajikan pada Tabel 7 berikut. 
Tabel 7.

Hasil Uji Signifikansi Simultan (F)

\begin{tabular}{llccccc}
\hline Model & & Sum of Squares & $d f$ & Mean Square & $F$ & Sig. \\
\hline 1 & Regression & 19,465 & 1 & 19,465 & 29,792 & $0,000^{\mathrm{b}}$ \\
& Residual & 77,096 & 118 & 0,653 & & \\
& Total & 96,560 & 119 & & & \\
\hline
\end{tabular}

Sumber: Data diolah, 2018

Tabel 7 menunjukkan bahwa nilai $\mathrm{F}_{\text {hitung }}$ yang diperoleh adalah sebesar 29,792 dengan signifikansi 0,000. Signifikansi ini lebih kecil dari nilai $\alpha=0,05$ maka model dalam persamaan regresi telah memenuhi prasyarat ketepatan fungsi regresi dan layak digunakan untuk memprediksi pengaruh kredit yang disalurkan pada profitabilitas.

Hipotesis kedua mengenai ukuran perusahaan dalam memoderasi pengaruh kredit yang disalurkan pada profitabilitas diuji menggunakan moderated regression analysis yang dapat dilihat pada Tabel 8 sebagai berikut.

Tabel 8.

Hasil Uji Moderated Regression Analysis

\begin{tabular}{|c|c|c|c|c|c|c|}
\hline \multirow{2}{*}{\multicolumn{2}{|c|}{ Model }} & \multicolumn{2}{|c|}{$\begin{array}{c}\text { Unstandardized } \\
\text { Coefficients }\end{array}$} & \multirow{2}{*}{$\begin{array}{c}\text { Standardized } \\
\text { Coefficients } \\
\text { Beta }\end{array}$} & \multirow[t]{2}{*}{$t$} & \multirow[t]{2}{*}{ Sig. } \\
\hline & & $B$ & Std. Error & & & \\
\hline \multirow[t]{4}{*}{1} & (Constant) & $-21,592$ & 7,509 & & $-2,876$ & 0,005 \\
\hline & LDR & 0,203 & 0,090 & 3,518 & 2,244 & 0,027 \\
\hline & Kapitalisasi Pasar & 0,757 & 0,263 & 1,426 & 2,878 & 0,005 \\
\hline & LDR*Kapitalisasi Pasar & $-0,006$ & 0,003 & $-3,724$ & $-2,060$ & 0,042 \\
\hline
\end{tabular}

Sumber: Data diolah, 2018

Berdasarkan hasil uji regresi linear sederhana pada Tabel 8, maka dapat dibuat persamaan regresi sebagai berikut:

$$
Y=-21,592+0,203 X_{1}+0,757 X_{2}-0,006 X_{1} X_{2}+7,509
$$


Interpretasi dari persamaan diatas yaitu jika nilai konstanta sebesar -21,592 memiliki arti jika variabel LDR dan kapitalisasi pasar dinyatakan konstan pada angka 0, maka variabel ROA bernilai sebesar -21,592 dengan asumsi variabel lainnya konstan. Koefisien regresi pada variabel LDR sebesar 0,203. Koefisien regresi yang bernilai positif memiliki arti jika LDR meningkat sebesar satu satuan, maka ROA juga akan meningkat sebesar 0,203 satuan dengan asumsi variabel lainnya konstan.

Koefisien regresi pada variabel kapitalisasi pasar sebesar 0,757. Koefisien regresi yang bernilai positif memiliki arti jika kapitalisasi pasar meningkat sebesar satu satuan, maka ROA juga akan meningkat sebesar 0,757 satuan dengan asumsi variabel lainnya konstan. Koefisien regresi pada variabel LDR x kapitalisasi pasar sebesar -0,006. Koefisien regresi yang bernilai negatif memiliki arti jika interaksi LDR dan kapitalisasi pasar meningkat sebesar satu satuan, maka ROA akan mengalami penurunan sebesar 0,006 satuan dengan asumsi variabel lainnya konstan.

Hasil pengujian statistik pengaruh ukuran perusahaan terhadap pengaruh kredit yang disalurkan pada profitabillitas dalam Tabel 8 menunjukkan bahwa koefisien regresi dari interaksi variabel kredit yang disalurkan dengan proksi LDR dan ukuran perusahaan dengan proksi kapitalisasi pasar adalah $-0,006$ serta nilai signifikansinya adalah 0,042 yaitu lebih kecil dari $\alpha=0,05$ yang berarti ukuran perusahaan memperlemah hubungan kredit yang disalurkan pada profitabilitas dengan ROA sebagai proksi, sehingga hipotesis yang diajukan dalam penelitian ini ditolak. 
Dalam model analisis MRA pada penelitian ini koefisien determinasi dilihat melalui nilai adjusted $R^{2}$, yang disajikan pada Tabel 9 berikut.

Tabel 9.

Koefisien Determinasi $\left(\mathbf{R}^{\mathbf{2}}\right)$

\begin{tabular}{ccccc}
\hline Model & $R$ & $R$ Square & Adjusted $R$ Square & Std. Error of the Estimate \\
\hline 1 & $0,612^{\mathrm{a}}$ & 0,375 & 0,359 & 0,72128 \\
\hline \multicolumn{2}{l}{ Sumber: Data diolah, 2018} & & &
\end{tabular}

Berdasarkan pada Tabel 9 diatas, dapat dilihat bahwa nilai dari adjusted $R$ square sebesar 0,359 dimana memiliki arti bahwa 35,9 persen variasi perubahan ROA dapat dijelaskan oleh LDR dan kapitalisasi pasar. Sedangkan sisanya sebesar 64,1 persen dipengaruhi oleh variabel lain diluar dari model regresi yang digunakan.

Uji F dilakukan dengan melihat nilai signifikansi pada tabel ANOVA ${ }^{\mathrm{a}}$ dengan bantuan program SPSS. Bila nilai signifikansi ANOVA $^{\mathrm{a}} \leq \alpha=0,05$ maka model ini dikatakan layak atau variabel bebas mampu menjelaskan variabel terikat. Adapun hasil dari uji F telah disajikan pada Tabel 10 berikut.

Tabel 10.

Hasil Uji Signifikasi Simultan (F)

\begin{tabular}{llccccc}
\hline \multirow{2}{*}{ Model } & & Sum of Squares & $d f$ & Mean Square & F & Sig. \\
\hline 1 & Regression & 36,212 & 3 & 12,071 & 23,202 & $0,000^{\mathrm{b}}$ \\
& Residual & 60,348 & 116 & 0,520 & & \\
& Total & 96,560 & 119 & & & \\
\hline
\end{tabular}

Sumber: Data diolah, 2018

Tabel 10 menunjukkan bahwa nilai $\mathrm{F}_{\text {hitung }}$ yang diperoleh adalah sebesar 23,202 dengan tingkat signifikansi 0,000. Signifikansi ini lebih kecil dari nilai $\alpha=$ 0,05 maka model dalam persamaan moderated regression analysis telah memenuhi prasyarat ketepatan fungsi regresi dan layak digunakan untuk 
memprediksi pengaruh ukuran perusahaan terhadap hubungan kredit yang disalurkan pada profitabilitas.

Berdasarkan uji regresi menunjukkan bahwa kredit yang disalurkan berpengaruh positif terhadap profitabilitas, dan hipotesis diterima. Hipotesis tersebut dapat diterima dan mendukung teori keagenan serta teori abstinence karena kegiatan penyaluran kredit merupakan kegiatan utama bank yang dilakukan untuk mencapai keberhasilan dalam memaksimalkan laba atau profitabilitas, dimana semakin tinggi tingkat kredit yang disalurkan oleh suatu bank maka akan diikuti oleh meningkatnya profitabilitas bank melaui pendapatan bunga, hal tersebut juga menunjukkan bahwa manajemen bank mampu menggunakan dana deposan secara berhati-hati terhadap keputusan investasi yang berisiko tinggi, seperti risiko kredit sehingga dapat memimalkan agency cost yang ditimbulkan dari agency problem dan berdampak positif terhadap profitabilitas perusahaan. Hasil penelitian ini sejalan dengan penelitian yang dilakukan oleh Astohar (2009) bahwa Loan to Deposit Ratio (LDR) perbankan memiliki pengaruh positif terhadap profitabilitas perbankan (ROA). Pernyataan tersebut diperkuat oleh penelitian Oktaviani dan Yusuf (2014) yaitu jumlah kredit yang disalurkan berpengaruh positif terhadap profitabilitas, dan Lukitasari dan Kartika (2015) yang menunjukkan bahwa semakin tinggi Loan to Deposit Ratio (LDR), maka laba (ROA) bank semakin meningkat (dengan asumsi bank tersebut mampu menyalurkan kreditnya dengan efektif). Dalam penelitian sejenis yang membahas pengaruh kredit yang disalurkan terhadap profitabilitas, Harun (2016) juga menyatakan bahwa LDR berpengaruh positif terhadap ROA. 
Berdasarkan uji regresi mnunjukkan bahwa ukuran perusahaan memperlemah hubungan antara kredit yang disalurkan dengan profitabilitas, dan hipotesis ditolak. Hasil penelitian ini tidak dapat mendukung teori keagenan dan teori basel II, disebabkan oleh nilai pasar saham atau kapitalisasi pasar yang tinggi dan merupakan cerminan dari ukuran perusahaan tidak serta merta akan meningkatkan profitabilitas perusahaan dan meminimalkan adanya agency problem. Kapitalisasi pasar (market capitalization) dapat mencerminkan saling melengkapi atau substitusi antara bank dan pembiayaan pasar modal, dengan kata lain market capitalization dapat memberikan dua pengaruh yang berbeda terhadap profitabilitas. Apabila dampak subtitusi lebih dominan, maka suatu negara yang memiliki pasar saham yang relatif berkembang dengan baik dapat menggantikan pembiayaan bank dan menyebabkan berkurangnya dana pihak ketiga dari nasabah, mengakibatkan penurunan margin bunga sehingga akan memberikan pengaruh negatif terhadap profitabilitas bank (Suteja dan Ginting, 2014). Terjadinya perubahan tingkat suku bunga acuan Bank Indonesia juga dapat menyebabkan manajer ragu untuk meningkatkan/menurunkan lending rate yang akan memberikan dampak positif ataupun negatif terhadap tingkat kapitalisasi pasar, penyaluran kredit serta profitabilitas perusahaan. Manajer dapat saja menginginkan untuk memperoleh keuntungan pribadi yang sebsesar-besarnya sehingga akan meningkatkan lending rate, dan berdampak terhadap tingginya minat investor untuk menginvestasikan dananya di saham perusahaan perbankan yang bersangkutan namun hal tersebut juga akan berdampak terhadap resiko kredit yang tinggi serta membahayakan dana pihak ketiga atau deposan maupun 
tingkat likuiditas perusahaan. Hasil penelitian ini didukung dengan penelitian yang dilakukan oleh Sayari dan Shamki (2016) serta Pan dan Pan (2014) yang menyatakan bahwa kapitalisasi pasar memiliki pengaruh negatif dan signifikan terhadap ROA.

Penelitian yang dilakukan diharapkan dapat memberikan kontribusi mengenai pengaruh kredit yang disalurkan pada profitabilitas dan ukuran perusahaan sebagai pemoderasi pada perusahaan subsektor perbankan yang tedaftar di Bursa Efek Indonesia tahun 2013-2017. Hasil uji dalam penelitian ini ditemukan bahwa kredit yang disalurkan berpengaruh positif terhadap profitabilitas, hal tersebut sejalan dengan teori abstinence, jika debitur menggunakan uang yang dipinjamnya dari kreditur untuk memenuhi keinginan pribadi, debitur wajib membayar sewa atas uang tersebut. Pembayaran sewa atau bunga yang dibebankan kepada debitur merupakan cara bagi kreditur untuk mendapatkan keuntungan, sama halnya dengan perusahaan perbankan. Hasil berikutnya dalam penelitian ini adalah ukuran perusahaan memperlemah hubungan antara kredit yang disalurkan terhadap profitabilitas, hasil tersebut tidak mampu mendukung teori basel II, disebabkan oleh kapitalisasi pasar disamping membantu dalam meningkatkan modal perusahaan untuk mengatasi risiko kredit, dapat pula menjadi subtitusi yang akan memberikan pengaruh positif maupun negatif terhadap profitabilitas. Kapitalisasi pasar juga dapat memperlemah tingkat penyaluran kredit yang berujung pada tingkat profitabilitas perusahaan, apabila terjadi perubahan tingkat suku bunga acuan Bank Indonesia sehingga menyebabkan manajer ragu untuk meningkatkan/menurunkan lending rate yang 
akan memberikan dampak positif ataupun negatif terhadap tingkat kapitalisasi pasar dan penyaluran kredit serta profitabilitas perusahaan.

Penelitian ini tentunya diharapkan untuk dapat memberikan implikasi bagi investor dan pihak perusahaan sebagai pertimbangan serta pengetahuan mengenai profitabilitas dan faktor-faktor yang mempengaruhinya, baik faktor internal maupun eksternal dalam menjalankan operasional perusahaan. Setiap investasi tentu mengandung unsur ketidakpastian, sehingga apabila terdapat kesempatan untuk berinvestasi, investor harus memperhatikan keputusannya, terlebih lagi jika investasi tersebut memiliki resiko yang tinggi. Hasil penelitian ini juga diharapkan dapat membantu pihak perusahaan perbankan dalam setiap pengambilan keputusan yang berkaitan dengan keuangan dikarenakan setiap keputusan keuangan tersebut mampu mempengaruhi kelangsungan hidup perusahaan.

\section{SIMPULAN}

Simpulan yang dapat diberikan berdasarkan hasil analisis data dan pembahasan yang telah diuraikan yaitu kredit yang disalurkan berpengaruh positif signifikan terhadap profitabilitas pada perusahaaan subsektor perbankan yang terdaftar di Bursa Efek Indonesia periode 2013 hingga 2017 dan ukuran perusahaan berpengaruh negatif signifikan terhadap hubungan antara kredit yang disalurkan pada profitabilitas di perusahaaan subsektor perbankan yang terdaftar di Bursa Efek Indonesia periode 2013 hingga 2017.

Kegiatan penyaluran kredit merupakan kegiatan utama bank yang dilakukan untuk mencapai keberhasilan dalam memaksimalkan laba atau profitabilitas, 
dimana semakin tinggi tingkat kredit yang disalurkan oleh suatu bank maka akan diikuti oleh meningkatnya profitabilitas bank. Kapitalisasi pasar (market capitalization) dapat mencerminkan saling melengkapi atau substitusi antara bank dan pembiayaan pasar modal, dengan kata lain market capitalization dapat memberikan dua pengaruh yang berbeda terhadap profitabilitas.

Saran yang dapat diberikan berkaitan dengan hasil penelitian serta untuk kesempurnaan penelitian selanjutnya yaitu bagi pihak perbankan agar tetap mengoptimalkan penyaluran kredit kepada masyarakat sehingga dapat meningkatkan profitabilitas perusahaan dan menarik minat investor untuk berinvestasi di saham perusahaan yang bersangkutan namun tetap memperhatikan risiko, seperti risiko kredit maupun risiko likuiditas perusahaan.

Bagi penelitian berikutnya diharapkan untuk menggunakan variabel dependen lainya sebagai proksi profitabilitas perbankan, seperti ROE ataupun NIM serta variabel independen lainnya yang turut mempengaruhi profitabilitas perbankan, seperti NPL, CAR dan yang lainnya

\section{REFERENSI}

Adawiyah, A. Z., \& Suprihhadi, H. (2017). Pengaruh Modal, Aset, dan Ukuran Perusahaan Terhadap Profitabilitas Perbankan. Jurnal Ilmu Dan Riset Manajemen, 6(1), 1-15.

Arif, M., Khan, M. Z., \& Iqbal, M. (2013). Impact of Bank Size on Profitability: Evidance From Pakistan. International Journal of Applied Research, 2, 98109.

Astohar. (2009). Faktor - Faktor yang Mempengaruhi Profitabilitas Perbankan di Indonesia. Tesis. Universitas Diponegoro. 
Bank Indonesia. Peraturan Bank Indonesia Nomor 6/10/PBI/2004 Tentang Sistem Penilaian Tingkat Kesehatan Bank Umum. (2004). Indonesia.

Bank Indonesia. Peraturan Bank Indonesia Nomor 13/1/PBI/2011 Tentang Penilaian Tingkat Kesehatan Bank Umum. (2011). Indonesia.

Bank Indonesia. Surat Edaran Bank Indonesia Nomor 6/23/DPNP Perihal Sistem Penilaian Tingkat Kesehatan Bank Umum. (2004). Indonesia.

Bećirović, S. (2015). An Analysis of TIme Preference Theory of Interet and Its Impact on The Business Environment. University Journal of Information Technology and Economics, 2(1), 5-13.

Bwacha, C. R., \& Xi, J. (2018). The Impact of Liquidity on Profitability: An Explanatory Study of The Banking Sector Between 2008 and 2017. Master's Thesis. UMEA School of Business, Economics and Statistics.

Christaria, F., \& Kurnia, R. (2016). The Impact of Financial Ratios , Operational Efficiency and Non Performing Loan Towards Commercial Bank Profitability. Global Academy of Training \& Research Journal, 1(1), 43-50.

Goddard, J., Molyneux, P., \& Wilson, J. O. S. (2004). The Profitability Of European Banks: A Cross-Sectional and Dynamic Panel Analysis. The Manchester School Journal, 72(3), 363-381.

Haneef, S., Riaz, T., Muhammad, R., Rana, M. A., Ishaq, H. M., \& Karim, Y. (2012). Impact of Risk Management on Non-Performing Loans and Profitability of Banking Sector of Pakistan. International Journal of Business and Social Science, 3(7), 307-315.

Hantono. (2017). Effect of Capital Adequacy Ratio (CAR), Loan to Deposit Ratio (LDR) and Non Performing Loan (NPL) to Return on Assets (ROA) Listed in Banking in Indonesia Stock Exchange. International Journal of Education and Research, 5(1), 69-80.

Harun, U. (2016). Pengaruh Ratio-Ratio Keuangan CAR, LDR, NIM, BOPO, NPL Terhadap ROA. Jurnal Riset Bisnis Dan Manajemen, 4(1), 67-82.

Hidayat, T., Hamidah, \& Mardiyati, U. (2012). Analisis Pengaruh Karakteristik Bank dan Inflasi Terhadap Net Interest Margin. Jurnal Riset Manajemen Sains Indonesia, 3(1), 1-15.

Japlani, A. (2015). Apakah Ukuran Itu Penting? Jurnal Akuisisi, 11(1), 1-21.

Lukitasari, Y. P., \& Kartika, A. (2015). Ananlisis Pengaruh Dana Pihak Ketiga, BOPO, CAR, LDR dan NPL Terhadap Kinerja Keuangan pada Sektor 
Perbankan yang Terdaftar di Bursa Efek Idonesia. Jurnal Infokam, 11(1), $28-39$.

Munir, A., \& Emdi, R. Z. (2017). Analysis Comparative of Probability Between Conventional Banks and Islamic Banks in Indonesia. International Journal of Humanities and Management Sciences, 5(1), 36-40.

Naceur, S. Ben, \& Omran, M. (2008). The Effects of Bank Regulations, Competition and Financial Reforms on MENA Banks'Profitability. Economic Research Forum.

Oktaviani, A., \& Yusuf, M. (2014). Pengaruh Jumlah Kredit yang Disalurkan Terhadap Profitabilitas Perbankan dengan Moderasi Resiko Kredit. Jurnal Manajemen Dan Akuntansi PRESTASI, 13(2), 30-45.

Otoritas Jasa Keuangan. (2014). Statistik Perbankan Indonesia 2013. Februari. Departemen Perizinan dan Infromasi Perbankan Otoritas Jasa Keuangan. Jakarta.

Otoritas Jasa Keuangan. (2015). Statistik Perbankan Indonesia 2014. Februari. Departemen Perizinan dan Infromasi Perbankan Otoritas Jasa Keuangan. Jakarta.

Otoritas Jasa Keuangan. (2016). Statistik Perbankan Indonesia 2015. Februari. Departemen Perizinan dan Infromasi Perbankan Otoritas Jasa Keuangan. Jakarta.

Otoritas Jasa Keuangan. (2017). Statistik Perbankan Indonesia 2016. Februari. Departemen Perizinan dan Infromasi Perbankan Otoritas Jasa Keuangan. Jakarta.

Otoritas Jasa Keuangan. (2018). Statistik Perbankan Indonesia 2017. Februari. Departemen Perizinan dan Infromasi Perbankan Otoritas Jasa Keuangan. Jakarta.

Pan, Q., \& Pan, M. (2014). The Impact of Macro Factors on the Profitability of China' s Commercial Banks in the Decade after WTO Accession. Journal of Social Science, 2, 64-69.

Permatasari, A. N., Rahardian, D., \& Yunita, I. (2017). Pengaruh CAR, LDR, BOPO, NPL dan Ukuran Perusahaan Terhadap Profitabilitas. E-Proceeding of Management, 4(2), 1296-1303.

Pramudita, A. (2013). Pengaruh Ukuran Bank, Manajemen Aset Perusahaan, Kapitalisasi Pasar dan Profitabilitas Terhadap Kredit Bermasalah pada Bank yang terdaftar di BEI. Jurnal Ilmiah Mahasiswa FEB, 2(1), 1-36. 
Rengasamy, Dhauskodi. (2014). Impact of Loan Deposit Ratio (LDR) on Profitability: Panel Evidence from Commercial Banks in Malaysia. Proceedings of the Third International Conference on Global Business, Economics, Finance and Social Sciences. Mumbai, India.

Risha, V. G. (2013). Pengaruh Kredit yang Diberikan, Likuiditas dan Kecukupan Modal Terhadap Profitabilitas. Jurnal Akuntansi, 2(1), 1-29.

Sayari, K., \& Shamki, D. (2016). Commercial Banks Profitability and Stock Market Developments. Journal of Applied Finance \& Banking, 6(4), 43-52.

Sufian, F. (2011). Profitability of the Korean Banking Sector : Panel Evidence on Bank-Specific and Macroeconomic Determinants 1 Introduction. Journal of Economics and Management, 7(1), 43-72.

Sugiyono. (2017). Metode Penelitian Kuantitatif, Kualitatif dan R\&D. Bandung: Alfabeta.

Suteja, J., \& Ginting, G. (2014). Determinan Profitabilitas Bank: Suatu Studi pada Bank yang Terdaftar di BEI. Jurnal Trikonomika, 13(1), 62-77.

Utami, I. A. T. I., \& Putra, I. N. W. A. (2016). Non Performing Loan Sebagai Pemoderasi Pengaruh Kredit yang Disalurkan pada Profitabilitas. E-Jurnal Akuntansi Universitas Udayana, 15(3), 2107-2133.

Utami, S. R. (2015). Comparison Between Bank Performance of Commercial Bank, State Owned Bank , and Foreign Owned Bank in Indonesia During The Period 2005-2009. International Journal of Advanced Research in Management and Social Sciences, 4(10), 37-54.

Zainuddin, P., Wancik, Z., Rahman, S. A., Hartati, S., \& Rahman, F. A. (2017). Determinant of Financial Performance on Indonesian Banks Through Return on Assets. International Journal of Applied Business and Economic Research, 15(20), 243-251. 